2. Альохин А.П., Кармлицкий А.А., Козлов Ю.М. Административное право Росийской Федерации: учебник. Москва : Зерцало, 1997. 296 с.

3. Тихомиров Ю.А. Курс административного права и процесса. Москва : Юринкомцентр, 1998. $652 \mathrm{c}$.

4. Колпаков В.К. Адміністративне право України : підручник. Київ : Юрінком Інтер, 1999. $736 \mathrm{c}$.

УДК 352: 322

DOI https://doi.org/10.32844/2618-1258.2019.5-1.32

ЗОЛОТОНОША О.в.

\title{
ІСТОРИЧНІ РЕТРОСПЕКТИВИ РОЗВИТКУ МІСЦЕВИХ ОРГАНІВ ВЛАДИ
}

Стаття присвячена дослідженню та розкриттю ретроспектив теорії місцевого самоврядування. Визначаються етапи його становлення на теренах незалежної України. Доводиться значимість місцевого самоуправління для подальшого суспільного й державного розвитку країни. Констатується неналежний стан розбудови місцевого самоврядування за роки незалежності України. Здійснено історико-правовий аналіз становлення законодавчого регулювання місцевої влади в Україні. Визначено, що синтез державного і громадського у самоврядуванні $є$ важливим для суспільства, оскільки не відбувається роздвоєння влади, яке може супроводжуватися політичною нестабільністю, відкриваються можливості для населення брати участь в управлінні громадсько-державними справами; ліквідується розрив між суспільством і державою; досягається єдина мета - збереження та зміцнення суспільства і держави за наявності демократичних інститутів; держава більшою мірою входить у курс місцевих справ та приймає відповідні рішення, сутність яких узгоджується з інтересами людей; породжується спільний інтерес для громадян та державних органів, сутність якого полягає у будівництві життя, гідного кожної людини та суспільства загалом; управління суспільством на основі узгоджених дій перетворюється на єдиний процес творення. 3'ясовано, що в Україні важливий інститут громадянського суспільства почав формуватися в світовій ліберально-політичній думці у першій половині XIX ст. Утілення ідеї місцевого самоврядування знайшло свій вияв у формуванні крайових представницьких органів Галичини та Буковини в складі Австрійської імперії другої половини XIX - початку XX ст., а також земств в українських губерніях Лівобережжя та Півдня України. Зроблено висновок, що розвиток органів місцевої влади пройшов велику кількість етапів і продовжується зараз. Інститут місцевого самоврядування $\epsilon$ невіддільною частиною сучасної демократичної держави. Він представляє собою сукупність органів і механізмів, з одного боку, а також принципів і методів - з іншого, за допомогою яких громадяни реалізують право на управління і вирішення публічних справ на найближчому для себе рівні. Відповідно, з метою подальшого реформування треба зробити низку кроків. Це дасть можливість забезпечити безповоротність змін і успіх.

Ключові слова: місиеві органи влади, самоврядування, громада, громадянське суспільство, децентралізачія, реформування, виконавча влада.

The article is devoted to the research and disclosure of the retrospective of the theory of local self-government. The stages of its formation on the territory of independent Ukraine are determined. The importance of local self-government for the further social and state development of the country is proved. The state of development of local self-government during the years of Ukraine's independence has been ascertained.

(c) ЗОЛОТОНОША О.В. - кандидат юридичних наук, докторант (Дніпропетровський державний університет внутрішніх справ) 
Historical and legal analysis of the formation of legislative regulation of local authorities in Ukraine is investigated. It is determined that the synthesis of state and public self-government is important for society, since there is no split of power, which can be accompanied by political instability, opportunities for the population to participate in the management of public-state affairs are opened; closing the gap between society and the state; the sole aim is to preserve and strengthen society and the state in the presence of democratic institutions; the state is more involved in the course of local affairs and makes appropriate decisions, the nature of which is consistent with the interests of the people; there is a common interest for citizens and public authorities, the essence of which is to build a life worthy of everyone and society as a whole; managing society through concerted action becomes a single process of creation. It was found out that in Ukraine the important institute of civil society began to take shape in the world liberal-political thought in the first half of the nineteenth century. The embodiment of the idea of local self-government was reflected in the formation of the regional representative bodies of Galicia and Bukovina in the Austrian Empire in the second half of the nineteenth - early twentieth centuries, as well as zemstvos in the Ukrainian provinces of the Left Bank and Southern Ukraine. It is concluded that the development of local authorities has passed a large number of stages and is still ongoing. The institution of local self-government is an integral part of a modern democratic state. It is a collection of bodies and mechanisms, on the one hand, and principles and methods, on the other, by which citizens exercise the right to manage and resolve public affairs at the nearest level. Accordingly, reform must be continued and a number of steps must be taken. This will ensure irreversibility of change and ensure success.

Key words: local authorities, self-government, community, civil society, decentralization, reform, executive power.

Вступ. Розвиток України як демократичної, соціальної та правової держави є неможливим без становлення дієвого місцевого самоврядування. Формування місцевого самоврядування виявилося одним із найбільш складних і суперечливих завдань становлення сучасної державності. На шляху демократичних процесів постав цілий комплекс політичних, економічних, соціальних, кадрових, психологічних та інших перепон. Системний характер муніципальної влади, її взаємозв'язків із державною владою та іншими інститутами політичної системи суспільства об'єктивно вимагає не тільки концептуального аналізу генезису інститутів місцевого самоврядування в історичній ретроспективі та виявлення чинників і умов становлення, системних та функціональних характеристик муніципальної влади в сучасній Україні, а й всебічного осмислення перспективного розвитку муніципальної демократії у контексті адміністративної та інших реформ. Місцеві органи влади беруть свій початок від спроби розв'язати проблему: чи має громада окрему, відмінну від держави, владу, чи вона $є$ незалежною від держави публічно-правовою корпорацією або міцно включена в державний організм і виконує функції органу держави.

Аналіз останніх досліджень і публікацій. Питанням розвитку місцевих органів влади присвячені роботи М. Аракеляна, М. Баймуратова, В. Бабаєва, В. Бакуменка, Ю. Делії, В. Кампо, А. Коваленка, В. Кравченка, М. Корецького, В. Куйбіди, О. Лазора, О. Лебединської, В. Мамонової, В. Цвєткова, Ю. Шарова, В. Шаповала та інших.

Постановка завдання. Метою статті $\epsilon$ дослідження етапів розвитку місцевих органів влади, які забезпечують громадянам високу якість життя шляхом повного використання місцевих ресурсів.

Результати дослідження. Хронологічні рамки дослідження досить умовні, оскільки локалізувати в часі розвиток цілого суспільного інституту доволі складно.

Історично склалося, що першою була науково обгрунтована теорія вільної громади. В основі цієї теорії лежала ідея природного права. Вважалося, що громада має право на самостійне і автономне існування від державної влади згідно зі своєю природою. Як права і свободи людини базуються на ідеї природних прав, так і територіальна громада, яка сформувалася природним шляхом, визнавалася незалежною від держави. Згідно з цією теорією поряд 3 трьома загальновизнаними конституційними владами (законодавчою, виконавчою та судовою) слід визнати й четверту - громадівську (комунальну або муніципальну) владу. Громада має право на самостійне та незалежне від центральної влади існування за своєю природою, причому держава не утворює, а лише визнає громаду [1]. 
Теорія вільної громади мала значний вплив на становлення і формування місцевого самоврядування, а також на розвиток законодавства у першій половині XIX ст.

Наступною теорією була господарська (громадсько-господарська) теорія місцевого самоврядування, яка намагалась обгрунтувати статус самоврядної громади як відмінного від держави суб'єкта права та акцентувалась на змісті комунальної діяльності. Ця теорія організації місцевої влади виникла в результаті поступового розвитку положень теорії прав вільної громади у пристосуванні їх до умов, коли у процесі історичного розвитку ускладнюються правові стосунки між суб'єктами суспільного життя і підвищується роль держави як регулятора цих стосунків. В основі громадсько-господарської теорії місцевого самоврядування знаходиться запозичене з теорії природних прав вільної громади положення про те, що територіальний колектив - це елемент насамперед громадянського суспільства.

Друга половина XIX ст. характеризується появою громадівської теорії органів місцевої влади. У цій теорії підтримувалася позиція протиставлення територіальної громади державі, повна автономія органів самоврядування [1].

У другій половині XIX ст. значного поширення набула державницька теорія місцевих органів влади. Ця теорія вбачала в місцевому самоврядуванні частину держави - одну з форм організації місцевого державного управління, спосіб децентралізації державної влади на місцевому рівні.

Певною модифікацією громадівської і державницької теорії місцевого самоврядування $\epsilon$ теорія муніципального дуалізму. Згідно з цією теорією органи місцевого самоврядування $\epsilon$ незалежними від держави лише в суто громадівських справах, до яких держава байдужа, а у сфері політичній розглядаються як органи держави, що виконують ії функції й повноваження.

Синтез державного і громадського у самоврядуванні, на думку прихильників теорії муніципального дуалізму, є важливим для суспільства, оскільки не відбувається роздвоєння влади, яке може супроводжуватися політичною нестабільністю, відкриваються можливості для населення брати участь в управлінні громадсько-державними справами; ліквідується розрив між суспільством і державою; досягається єдина мета - збереження та зміцнення суспільства і держави за наявності демократичних інститутів; держава більшою мірою входить у курс місцевих справ та приймає відповідні рішення, сутність яких узгоджується з інтересами людей; породжується спільний інтерес для громадян та державних органів, сутність якого полягає у будівництві життя, гідного кожної людини та суспільства загалом; управління суспільством на основі узгоджених дій перетворюється на єдиний процес творення. Але здійснення цих переваг можливе лише в соціально орієнтованій державі [1].

В Україні вибір зроблено на користь громадівської теорії місцевого самоврядування. Водночас ряд ознак вітчизняної моделі місцевої влади (збереження інституту районних і обласних рад, широке коло делегованих місцевому самоврядуванню повноважень виконавчої влади, конституювання інституту місцевих державних адміністрацій та інші) свідчать про суттєвий залишковий вплив державної теорії місцевого самоврядування і теорії муніципального дуалізму.

В Україні важливий інститут громадянського суспільства, почав формуватися в світовій ліберально-політичній думці у першій половині XIX ст. Утілення ідеї місцевого самоврядування знайшло свій вияв у формуванні крайових представницьких органів Галичини та Буковини в складі Австрійської імперії другої половини XIX - початку XX ст., а також земств в українських губерніях Лівобережжя та Півдня України. Земства стали основою для формування опозиції самодержавному режиму. Із приходом до влади більшовиків досвід діяльності місцевого самоврядування на тривалий час було втрачено [2, с. 56].

Початком відродження в Україні місцевого самоврядування можна вважати вибори до Верховної Ради УРСР та місцевих рад народних депутатів у березні 1990 р. Унаслідок виборчого процесу до рад різних рівнів потрапили люди, які доволі часто були далекі від номенклатурно-партійної системи управління країною. Відносини у цій сфері регулювалися в той час постановою Президії Верховної Ради СРСР «Про примірне положення голів і президії місцевих рад народних депутатів» від 20 жовтня 1989 р. і Законом СРСР «Про загальні засади місцевого самоврядування і місцевого господарства в СРСР» від 9 квітня 1990 р. У радах на місцях з'явилися президії і голови, яких до цього часу не існувало. Ради обирали голову виконкому, котрий виконував функції головної посадової особи адміністративно-територіальної одиниці [3, с. 78].

Епохальним документом для становлення нової системи влади на теренах нашої держави стала Декларація про державний суверенітет від 16 липня 1990 р. Вперше проголошувалася відмова від радянської системи публічної влади, було задекларовано демократичні принципи їі організації. Тому вже 7 грудня 1990 р. Верховна Рада УРСР прийняла Закон «Про місцеві ради народних депутатів УРСР та місцеве самоврядування». 
Попри те, що чинними залишалися положення Конституції УРСР 1978 р., які відносили місцеві ради до державних органів місцевого самоврядування, та ще існували так звані «радянські трьошки» із підпорядкуванням нижчестоящих рад вищестоящим (ст. 3 Конституції УРСР), прийняття документа відкрило нову сторінку історії місцевого самоврядування на українських землях. Документ проголошував самостійність і незалежність рад у межах своїх повноважень, їхнє самофінансування і самозабезпечення. Згідно із законом система місцевого самоврядування включала в себе форми безпосереднього волевиявлення населення.

Після проголошення незалежності України розбудова місцевої влади продовжилася. 5 березня 1992 р. за ініціативи Президента Л. Кравчука було прийнято Закон України «Про Представника Президента України». На цей інститут покладалися функції здійснення державної виконавчої влади і контролю за органами місцевого самоврядування. Згідно із документом Представник Президента був найвищою посадовою особою державної виконавчої влади в області і районі, він здійснював загальне керівництво місцевою державною адміністрацією, забезпечував виконання районного та обласного бюджетів, контролював дотримання Конституції та законодавства [4].

26 березня 1992 р. було прийнято нову редакцію Закону «Про місцеві ради народних депутатів Української РСР та місцеве самоврядування»[5]. Передбачалася передача частини повноважень від рад представникам Президента. На районному і обласному рівнях ради народних депутатів позбавлялися власних виконкомів і мали характер винятково представницьких органів. 3 метою вдосконалення системи організації місцевої влади 3 лютого 1994 р. було скасовано інститут місцевої державної адміністрації.

Відтоді голови рад усіх рівнів обиралися населенням відповідних адміністративно-територіальних одиниць, а замість державних адміністрацій у районах і областях знову відновлювались виконкоми.

В умовах складного конституційного процесу новим документом, який на конституційному рівні врегулював організацію місцевої влади, став Конституційний договір про основні засади організації і функціонування центральної і місцевої влади на період до прийняття нової Конституції від 8 червня 1995 р. - своєрідний компроміс між різними гілками влади.

Із прийняттям Конституції України, ст. 7 якої встановлювала, що в Україні визнається і гарантується місцеве самоврядування, розпочався новий етап еволюційного розвитку місцевого самоврядування в Україні. Слід зауважити, що розділ Основного Закону про місцеве самоврядування в кожному із проектів Конституції був досить дискусійним, оскільки існувало чимало пропозицій з боку науковців і правників. Зауваження таких організацій, як Асоціація міст України, Комісія з питань державного будівництва, діяльності рад і місцевого самоврядування враховано народними депутатами під час прийняття 21 травня 1997 р. Закону України «Про місцеве самоврядування» [6]. Закон визначив сутність місцевого самоврядування досить чітко, а саме, що це $\epsilon$ «гарантоване державою право і реальна можливість територіальної громади - жителів села, селища, міста - самостійно або під відповідальність органів і посадових осіб місцевого самоврядування вирішувати питання місцевого значення в межах Конституції і законів України».

В подальшому оберти зростають, формування органів місцевої влади відбувається шляхом реформування, приймається низка нормативно-правових актів як Президента України, Кабінету міністрів України, так і недержавних громадських утворень, які стосуються проблем повноважень органів влади та місцевого самоврядування. Серед таких документів необхідно виділити Концепцію адміністративної реформи в Україні [7]; Концепцію державної регіональної політики [7]; Указ Президента України «Про державну підтримку розвитку місцевого самоврядування в Україні» [8]; Послання Президента України до Верховної Ради України «Україна: поступ у XXI століття. Стратегія економічної та соціальної політики на 2000-2004 рр.» [9]; Концепцію реформи адміністративно-територіального устрою; Концепцію реформування місцевого самоврядування та територіальної організації влади [8]; Концепцію реформування публічної адміністрації [7] та інші.

Однією з важливих проблем, яка простежується в цих документах, є вдосконалення діяльності органів влади та місцевого самоврядування в частині функціонального розмежування повноважень цих органів. Проте в цих документах недостатньо уваги приділяється питанню створення механізму забезпечення прав місцевого населення шляхом розмежування цих повноважень. Особливо це стосується нормативно-правових актів, що регламентують шляхи реформування діяльності органів влади та самоврядування.

Упроваджені в подальшому Концепція державної регіональної політики та Указ Президента України «Про державну підтримку розвитку місцевого самоврядування в Україні» вбачали 
вирішення проблеми вдосконалення розподілу повноважень та функцій між територіальними підрозділами центральних органів виконавчої влади, місцевими державними адміністраціями та органами місцевого самоврядування у становленні місцевого самоврядування [7].

У 2011-2013 рр. на державному рівні було здійснено чимало спроб поновити процедуру реформування територіальної організації влади та місцевого самоврядування. Чого варті тільки кілька проектів, розміщених на сайті Державного фонду сприяння місцевому самоврядуванню в Україні, - «Проект Концепції реформування місцевого самоврядування та територіальної організації влади в Україні»; «Проект Концепції реформування місцевого самоврядування в Україні» (підготовлений Асоціацією міст України); «Проект Концепції територіальної організації влади в Україні» (підготовлений Українською асоціацією районних та обласних рад) та інші.

Так, проект Координаційної ради $з$ питань розвитку громадянського суспільства при Президентові України «Про Концепцію реформування місцевого самоврядування та територіальної організації влади» [8] передбачав поетапне виконання плану реформування місцевого самоврядування, зокрема 2012 року - «розподіл повноважень між органами місцевого самоврядування різних рівнів, місцевими органами виконавчої влади, територіальними органами центральних органів виконавчої влади та визначення повних і виключних власних повноважень, прав та відповідальності органів місцевого самоврядування за надання послуг жителям відповідних територіальних громад».

У період 32013 до 2015 року - «визначення повноважень органів місцевого самоврядування районів та областей».

Також розроблені різними державними та недержавними установами проекти законів «Про місцеве самоврядування в Україні» та «Про місцеві державні адміністрації» (проекти 2010 р.) [7]; «Про об’єднання територіальних громад» (проект 2011 р.) [8]; «Про місцеве і регіональне самоврядування в Україні» (проект 2012 р.) [7]; «Про службу в органах місцевого самоврядування» (проекти 2013 р.) [10] на початок 2014 р. залишаються на стадії «доопрацювання».

На цей час Уряд України працює над тим, щоб у 2020 році завершити реформу системи місцевого самоврядування, яка базується на Європейській Хартії місцевого самоврядування, провести місцеві вибори на новій територіальній основі і створити в громадах спроможну мережу закладів для надання доступних і якісних публічних послуг.

Мета Уряду - забезпечити для усіх жителів України можливість жити у спроможних громадах і отримували якісні публічні послуги і сервіси.

У 2020 році мають відбутися фундаментальні зміни в системі місцевого самоврядування та в адміністративно-територіальному устрої країни.

Таким чином, в Уряді і Парламенті більшість рішень з децентралізації не прийматимуть, а готуватимуть. Але мінімум два важливих закони Верховна Рада все ж розгляне до кінця сесії (закінчується у січні 2020 року) [11].

По-перше, на цій сесії народні депутати у першому читанні мають розглянути зміни до Конституції в частині децентралізації. Це голосування покаже, чи є у Верховної Ради цього скликання воля для завершення децентралізації через зміни до Конституції. Якщо голосування буде позитивним, подальша розробка законопроектів буде відштовхуватися від майбутніх змін до Основного закону. Якщо ж ні, треба буде знову намагатися продовжувати реформу без конституційних змін і до місцевих виборів 2020 року реформувати хоча б базовий (громади) і частково субрегіональний (райони) рівні місцевого самоврядування, чітко розподілити повноваження між ними.

Другий важливий закон, який також варто ухвалити на цій сесії Парламенту - «Про засади адміністративно-територіального устрою». Цей закон потрібен, зокрема, для того, щоб Уряд отримав повноваження і вже почав розробляти майбутній адміністративно-територіальний устрій. Новий адмінтерустрій майже не залежить від змін до Конституції, тому працювати над ним вже можна [11].

Висновки. Отже, розвиток органів місцевої влади пройшов велику кількість етапів і на цей час продовжується. Інститут місцевого самоврядування є невіддільною частиною сучасної демократичної держави. Він представляє собою сукупність органів і механізмів, з одного боку, а також принципів і методів - з іншого, за допомогою яких громадяни реалізують право на управління і вирішення публічних справ на найближчому для себе рівні. Відповідно, реформування має продовжуватись. Це дасть можливість забезпечити безповоротність змін і успіх. 


\section{Список використаних джерел:}

1. Хріпливець Д.Є. Теоретичні засади моделей місцевого самоврядування. URL: http://www.dy.nayka.com.ua/?op=1\&z=188.

2. Никончук А.М. Розвиток та формування системи місцевого самоврядування в сучасній Україні. Право і суспільство. 2011. № 6.

3. Батанов О.В. Муніципальне право України : Підручник. Харків : Одіссей, 2008. С. 172.

4. Про Представника Президента України: Закон України від 5 березня 1992 року. Відомості Верховної Ради України. 1992. № 23. Ст. 335.

5. Про місцеві Ради народних депутатів та місцеве і регіональне самоврядування: Закон України від 7 грудня 1990 року (в редакції від 26 березня 1992 року). Відомості Верховної Ради Украӥни. 26 березня. 1992. № 28. Ст. 387.

6. Про місцеве самоврядування в Україні: Закон України від 21 травня 1997 року. Вiдомості Верховної Ради Украӥни. 1997. № 24. Ст. 170.

7. Офіційний веб-портал Верховної Ради України. URL: http://w1.c1.rada.gov.ua/pls/zweb2/ webproc4 2? id $=\& p f 3516=9590 \&$ skl $=7$.

8. Офіційний веб-портал Верховної Ради України. URL: http://w1.c1.rada.gov.ua/pls/zweb2/ webproc4_2?id=\&pf3516=10025\&skl=7.

9. Н̈аціональне агентство з питань державної служби. URL: www.nads.gov.ua/control/uk/ publish/article;jsessionid=0BB2.

10. Павлович-Сенета Я.П. Розподіл повноважень між органами державної влади та місцевого самоврядування - один із напрямів реформування адміністративно-територіального устрою в Україні. URL: http://vuzlib.com/content/view/2244/10.

11. Децентралізація влади. URL: http://elanets.mk.gov.ua/ua/rda/1408437867/.

КАРМАЛІТА М.В.

\section{ВПЛИВ ПРИВАТНОГО ТА ПУБЛІЧНОГО ІНТЕРЕСУ НА ПРАВОВЕ РЕГУЛЮВАННЯ ВІДНОСИН У СФЕРІ ОПОДАТКУВАННЯ}

Публікацію присвячено аналізу актів правотворчої діяльності на предмет реалізації приватного та публічного інтересу в оподаткуванні. Встановлено, що результати правотворення є правовим виразом мотивів, вимог, пропозицій, які породжуються інтересами. Дослідження прояву приватного та публічного інтересу в податкових правовідносинах дало змогу констатувати, що приватний та публічний інтерес $є$ взаємопов'язаними категоріями у правовому регулюванні податкових відносин; право є засобом реалізації та захисту кожного $з$ них; у межах сфери оподаткування відбувається як поєднання приватного та публічного інтересу, так і їхнє протистояння. Проілюстровано на конкретних нормах національного права прагнення уповноваженого суб'єкта створити умови для забезпечення реалізації приватного та публічного інтересу в оподаткуванні. Інтересом в оподаткуванні пропонується розуміти прагнення учасників публічних суспільних відносин задовольнити економіко-соціальні потреби шляхом формування необхідного фінансового забезпечення завдяки податковим надходженням. У вітчизняному законодавстві відсутнє визначення приватного та публічного інтересу в оподаткуванні. Проблему балансу приватного та публічного інтересу необхідно вирішувати завдяки системному підходу, використовуючи історичну генезу кожного окремо в контексті правоутворення, а також тісному їхньому взаємозв’язку та взаємовпливі.

(C) КАРМАЛІТА М.В. - кандидат юридичних наук, доцент, докторант (Університет державної фіскальної служби України) 